- Karin Zattar Cecyn

- José Salvador Rodrigues de O liveira

- Antônio Correia Alves

- Maria Regina Regis Silva

- José Kerbauy

\title{
Prognostic factors in non-Hodgkin lymphomas
}

\author{
Department of $\mathrm{H}$ ematology and Transfusion M edicine, \\ U niversidade Federal de São Paulo/E scola Paulista de M edicina, São Paulo, Brazil
}

\section{abstract}

CONTEXT: In Hodgkin's disease, each clinical or pathologic stage can be related to the extent of the area involved and predicts the next a natomical region at risk for tumor dissemination.

OBJ ECTIVE: To determine the best prognostic factors that could predict survival in non-Hodgkin lymphoma cases.

DESIGN : A retrospective study.

LOCATION: Department of Hematology and Transfusion Medicine, Universidade Federal de São Paulo - Escola Paulista de Medicina.

PARTICIPANTS: 142 patients with non-Hodgkin lymphoma diagnosed between February 1988 and March 1993.

MAIN MEASUREMENTS: Histological subset, Sex, Age, Race, B symptoms, Performance status, Stage, Extranodal disease, Bulk disease, Mediastinal disease, CN S involvement, BM infiltration, Level of DHL, Immunophenotype.

RESULTS: In the first study (113 patients), the following variables had a worse influence on survival: yellow race $(P<0.1)$; ECO G II, III e IV $(P<0.1)$ and extranodal disease $(P<0.1)$ for high grade lymphomas; constitutional symptoms ( $P<0.1)$, ECO G II, III e IV $(P<0.1)$ and involvement of CN S $(P<0.1)$ for intermediate grade and the subtype lymphoplasmocytoid $(P=0.0186)$ for low grade lymphomas. In the second survey (93 patients), when treatment was included, the variables related to NHL survival were: $C N S$ involvement $(P<0.1)$ for high grade lymphomas, constitutional symptoms $(P<0.1), E C O G \|$, III, IV ( $P=0.0185)$ and also CN S involvement $(P<0.1)$ for the intermediate group. There were no variables related to the survival for low-grade lymphomas.

CONCLUSIONS: The intermediate grade lymphomas were more compatible with data found in the literature, probably because of the larger number of patients. In this specific case, the treatment did not have an influence on the survival.

KEY-WORDS: N on-Hodgkin lymphoma. Prognostic Factors. Survival.

\section{INTRODUCTION}

In Hodgkin's disease, each clinical or pathologic stage can be related to the extent of the area involved and predicts the next anatomical region at risk for tumor dissemination. Thus, the Ann Arbor staging criteria ${ }^{1,2}$ are useful in planning treatment and determining the evolution of the disease. However, the biological behavior of non-Hodgkin lymphomas (NHL) is much more complex in relation to their presentation and natural history. In this way, discrepancies between $\mathrm{NHL}$ found in the various subgroups make it impossible to analyze them all together, and in particular we cannot predict survival based only on the anatomical areas involved.

Age, general condition at the time of diagnosis, serum lactate dehydrogenase (LDH) level, extranodal involvement and tumor burden assessment are the factors that have been shown to have prognostic value for survival in many studies. ${ }^{3-7}$ There are some variations between the different authors. We studied all these parameters in order to understand better which of these could predict survival among a set of patients of low socioeconomic level treated in a public hospital in the city of São Paulo.

\section{METHODS}

An initial analysis of 142 patients with NHL was made, whose biopsies were reviewed and classified in accordance with the Working Formulation (WF) ${ }^{8}$ between February 1988 and March 1993 in our institution. From this, 29 patients were excluded due ineligible data, 
leaving the 113 patients that constituted our first study. A second analysis was carried out on 93 patients who completed their follow-up and could be evaluated as regards their treatment.

The staging of the disease were done before and after treatment. The tests performed included: com-

Table 1- Characteristics of patients with high grade lymphoma

\begin{tabular}{|c|c|c|c|c|}
\hline \multirow[b]{2}{*}{ Variables } & \multicolumn{2}{|c|}{$1^{\text {st }}$ analysis } & \multicolumn{2}{|c|}{$2^{\text {nd }}$ analysis } \\
\hline & nopatients & P-value & nopatients & P-value \\
\hline \multicolumn{5}{|l|}{ Histological subset } \\
\hline Immunoblastic & 12 & 0.42 & 09 & 0.54 \\
\hline SN C C & 02 & & 01 & \\
\hline Lymphoblastic & 03 & & 03 & \\
\hline Unclassified & 04 & & 03 & \\
\hline \multicolumn{5}{|l|}{ Sex } \\
\hline Female & 05 & 0.06 & 11 & 0.15 \\
\hline Male & 16 & & 05 & \\
\hline \multicolumn{5}{|l|}{ Age (years) } \\
\hline$<60$ & 19 & 0.92 & 14 & 0.42 \\
\hline$>60$ & 02 & & 02 & \\
\hline \multicolumn{5}{|l|}{ Race } \\
\hline W hite & 15 & 0.04 & 11 & 0.07 \\
\hline Black & 04 & & 04 & \\
\hline Yellow & 02 & & 01 & \\
\hline \multicolumn{5}{|l|}{ B symptoms } \\
\hline Present & 13 & 0.15 & 09 & 0.62 \\
\hline Absent & 08 & & 07 & \\
\hline \multicolumn{5}{|l|}{ Performance status } \\
\hline 0 & 03 & $<0.01$ & 02 & 0.52 \\
\hline 1 & 12 & & 10 & \\
\hline 2 & 04 & & 03 & \\
\hline 3 & 04 & & 01 & \\
\hline 4 & 01 & & 00 & \\
\hline \multicolumn{5}{|l|}{ Stage } \\
\hline I & 02 & 0.09 & 02 & 0.13 \\
\hline II & 07 & & 04 & \\
\hline III & 06 & & 05 & \\
\hline IV & 06 & & 05 & \\
\hline \multicolumn{5}{|l|}{ Extranodal disease } \\
\hline Present & 03 & $<0.01$ & 03 & 0.06 \\
\hline Absent & 18 & & 13 & \\
\hline \multicolumn{5}{|l|}{ Bulk disease } \\
\hline Present & 10 & 0.63 & 08 & 0.48 \\
\hline Absent & 11 & & 08 & \\
\hline \multicolumn{5}{|l|}{ Mediastinal disease } \\
\hline Present & 06 & 0.63 & 04 & 0.87 \\
\hline Absent & 15 & & 12 & \\
\hline \multicolumn{5}{|l|}{ CNS involvement } \\
\hline Present & 01 & 0.14 & 01 & $<0.01$ \\
\hline Absent & 16 & & 15 & \\
\hline \multicolumn{5}{|l|}{ BM infiltration } \\
\hline Present & 05 & 0.30 & 04 & 0.17 \\
\hline Absent & 16 & & 12 & \\
\hline \multicolumn{5}{|l|}{ Level of DHL } \\
\hline$\leq 225 \mathrm{U} / \mathrm{dl}$ & 04 & 0.88 & 04 & 0.14 \\
\hline$>225$ and $<450 \mathrm{U} / \mathrm{dl}$ & 06 & & 05 & \\
\hline$\geq 450 \mathrm{U} / \mathrm{dl}$ & 04 & & 02 & \\
\hline \multicolumn{5}{|l|}{ Immunophenotype } \\
\hline$B$ & 09 & 0.50 & 06 & 0.65 \\
\hline $\mathrm{T}$ & 01 & & 01 & \\
\hline
\end{tabular}

SN CC = malignant lymphoma small non-cleaved cell; DSCC = malignant lymphoma diffuse small cleaved cell; DMSLC = malignant lymphoma diffuse mixed small and large cell; $D L C=$ malignant lymphoma diffuse large cell; FM SC LC = malignant lymphoma follicular mixed small cleaved and large cell; $\mathrm{BM}=$ bone marrow . plete and differential blood cell count; biochemistry test, particularly the LDH level; chest $x$-ray; chest, abdomen and pelvis CT scans; and bilateral bone marrow biopsies. Some special procedures such as lumbar puncture, brain CT or percutaneous liver biopsy were performed only if there was clinical suspicion of local involvement. Each patient was characterized using the following remission criteria after treatment: complete remission (CR), defined as a complete absence of any clinical or laboratory (biochemical or radiological) signs of disease maintained for at least four sequential weeks; partial remission (PR), defined as a reduction in tumor burden of $50 \%$ or more, measurable in two dimensions at the same time; refractory disease (RD), defined as a reduction in tumor burden of less than $50 \%$ compared with the original size, or a complete failure of response to treatment, or evidence of growing tumor burden during two sequential therapy cycles. The disease free-survival (DFS) was taken as the length of time between $\mathrm{CR}$ and the last consultation or the relapse. The overall survival (OS) used the same criteria for all patient situations.

The following clinical variables were evaluated: age in years; sex; race; general condition (performance status) in accordance with the Eastern Cooperative Oncology Group (ECOG); ${ }^{8}$ extranodal site involvement; presence of bulk disease defined as a tumor burden mass larger than $10 \mathrm{~cm}$ in one diameter or occupying more than one third of the mediastinum; and CNS involvement. The LDH level was scored at three levels: $\leq 225 \mathrm{U} / \mathrm{dl}$; $>225$ and $<450 \mathrm{U} / \mathrm{dl}$; and $\geq 450 \mathrm{U} / \mathrm{dl}$. Biopsies from different disease sites, mostly lymphoid nodes, were reviewed in the Pathology Department and reclassified according to the WF. When there were plenty of samples, immunohistological studies were done on the $B$ (CD-20) and T (CD45RO) markers using the $A B C$ method. ${ }^{9}$ The clinical stages were determined in accordance with the Ann Arbor classification. Seven different, non-randomized chemotherapy regimens were used. These were chosen based on the initial WF histological classification. The second and third generation schemes such as $M$ acop- $B,{ }^{7}$ Promace$\mathrm{CYTAbom}^{8}$ and the BFM-83 high-risk protocol ${ }^{9}$ were used for high grade groups. $\mathrm{CHOP},{ }^{10} \mathrm{BACOP}^{10}$ and $M V P{ }^{11}$ were used for intermediate groups. For low grade Iymphoma, $\mathrm{COP}^{11}$ and MVPP ${ }^{11}$ were the most often used protocols.

Statistical M ethods. Survival curves were plotted according to the method of Kaplan and Meier. ${ }^{12}$ Statistical significance among curves was determined by the Cox-Mantel method, measuring variables with two categories of results, and the generalized Wilcoxon test 
for those variables with more than two categories of results.

\section{RESULTS}

Patients' parameters in relation to the grade of lymphoma are shown in Tables 1 to 3 and the distribution of the 93 treated patients among the different

Table 2- Characteristics of patients with intermediate grade lymphomas

\begin{tabular}{|c|c|c|c|c|}
\hline \multirow[b]{2}{*}{ Variables } & \multicolumn{2}{|c|}{$1^{\text {st }}$ analysis } & \multicolumn{2}{|c|}{$2^{\text {nd }}$ analysis } \\
\hline & nopatients & P-value & nopatients & P-value \\
\hline \multicolumn{5}{|l|}{ Histological subset } \\
\hline $\mathrm{DSCC}$ & 26 & 0.22 & 20 & 0.54 \\
\hline DM SLC & 21 & & 17 & \\
\hline DLC & 18 & & 15 & \\
\hline \multicolumn{5}{|l|}{ Sex } \\
\hline Female & 34 & 0.29 & 28 & 0.25 \\
\hline Male & 31 & & 24 & \\
\hline \multicolumn{5}{|l|}{ Age (years) } \\
\hline$<60$ & 47 & 0.96 & 41 & 0.13 \\
\hline$>60$ & 18 & & 11 & \\
\hline \multicolumn{5}{|l|}{ Race } \\
\hline W hite & 43 & 0.09 & 34 & 0.68 \\
\hline Black & 22 & & 18 & \\
\hline \multicolumn{5}{|l|}{ B Symptoms } \\
\hline Present & 43 & $<0.01$ & 34 & $<0.01$ \\
\hline Absent & 22 & & 18 & \\
\hline \multicolumn{5}{|l|}{ Performance status } \\
\hline 0 & 09 & $<0.01$ & 06 & 0.02 \\
\hline 1 & 38 & & 33 & \\
\hline 2 & 14 & & 11 & \\
\hline 3 & 02 & & 02 & \\
\hline 4 & 02 & & & \\
\hline \multicolumn{5}{|l|}{ Stage } \\
\hline | & 02 & 0.42 & 01 & 0.29 \\
\hline$\|$ & 19 & & 17 & \\
\hline III & 16 & & 12 & \\
\hline IV & 28 & & 22 & \\
\hline \multicolumn{5}{|l|}{ Extranodal disease } \\
\hline Present & 34 & 0.48 & 30 & 0.36 \\
\hline Absent & 31 & & 22 & \\
\hline \multicolumn{5}{|l|}{ Bulk disease } \\
\hline Present & 39 & 0.11 & 30 & 0.07 \\
\hline Absent & 26 & & 20 & \\
\hline \multicolumn{5}{|l|}{ Mediastinal Disease } \\
\hline Present & 20 & 0.87 & 18 & 0.65 \\
\hline Absent & 45 & & 34 & \\
\hline \multicolumn{5}{|l|}{ CNS involvement } \\
\hline Present & 04 & $<0.01$ & 04 & $<0.01$ \\
\hline Absent & 39 & & 39 & \\
\hline \multicolumn{5}{|l|}{ BM Infiltration } \\
\hline Present & 24 & 0.17 & 36 & 0.09 \\
\hline Absent & 40 & & 16 & \\
\hline \multicolumn{5}{|l|}{ Level of DHL } \\
\hline$\leq \mathrm{l} 250 \mathrm{U} / \mathrm{dl}$ & 14 & 0.06 & 10 & 0.14 \\
\hline$>250$ and $<450 \mathrm{U} / \mathrm{dl}$ & 27 & & 24 & \\
\hline$\geq 450 \mathrm{U} / \mathrm{dl}$ & 12 & & 09 & \\
\hline \multicolumn{5}{|l|}{ Immunophenotype } \\
\hline B & 31 & 0.50 & 23 & 0.24 \\
\hline$T$ & 07 & & 05 & \\
\hline
\end{tabular}

N CC = malignant lymphoma small non-cleaved cell; SCC = malignant lymphoma diffuse small cleaved cell; DMSLC = malignant lymphoma diffuse mixed small and large cell; DLC = malignant lymphoma diffuse large cell; FM SCLC = malignant lymphoma follicular mixed small cleaved and large cell; $\mathrm{BM}=$ bone marrow chemotherapy schemes is shown in Table 4.

The remission rates for high-grade lymphomas were: $62 \%$ CR, $25 \%$ PR and $12 \%$ RD; for the intermediate group: $50 \% \mathrm{CR}, 27 \% \mathrm{PR}$ and $23 \% \mathrm{RD}$; and for the low grade group: $44 \% C R$, $32 \% \mathrm{PR}$ and $24 \%$ RD. MACOP$\mathrm{B}$ and $\mathrm{CHOP}$ were the treatments analyzed for high grade lymphoma and their CR were $66 \%$ and $40 \%$ respectively $(P=0.777)$. For the intermediate grade, the

\section{Table 3 - Characteristics of patients with low grade lymphomas}

\begin{tabular}{|c|c|c|c|c|}
\hline \multirow[b]{2}{*}{ Variables } & \multicolumn{2}{|c|}{$1^{\text {st }}$ analysis } & \multicolumn{2}{|c|}{$2^{\text {nd }}$ analysis } \\
\hline & nqpatients & P-value & nopatients & P-value \\
\hline \multicolumn{5}{|c|}{ Histological subtype } \\
\hline FMSCLC & 12 & 0.02 & 11 & 0.29 \\
\hline Lymphoplasmocytoid & 03 & & 02 & \\
\hline Small Lymphocytes & 12 & & 12 & \\
\hline \multicolumn{5}{|l|}{ Sex } \\
\hline Female & 11 & 0.14 & 10 & 0.19 \\
\hline Male & 16 & & 15 & \\
\hline \multicolumn{5}{|l|}{ Age (years) } \\
\hline$<60$ & 24 & 0.98 & 23 & 0.45 \\
\hline$>60$ & 03 & & 02 & \\
\hline \multicolumn{5}{|l|}{ Race } \\
\hline W hite & 18 & 0.21 & 17 & 0.15 \\
\hline Black & 09 & & 08 & \\
\hline \multicolumn{5}{|l|}{ B Symptoms } \\
\hline Present & 20 & 0.10 & 19 & 0.06 \\
\hline Absent & 07 & & 06 & \\
\hline \multicolumn{5}{|l|}{ Performance Status } \\
\hline 0 & 04 & 0.21 & 04 & 0.21 \\
\hline 1 & 14 & & 14 & \\
\hline 2 & 07 & & 05 & \\
\hline 3 & 02 & & 02 & \\
\hline 4 & 00 & & 00 & \\
\hline \multicolumn{5}{|l|}{ Stage } \\
\hline I & 03 & 0.26 & 03 & 0.26 \\
\hline$\|$ & 03 & & 03 & \\
\hline III & 07 & & 07 & \\
\hline IV & 14 & & 14 & \\
\hline \multicolumn{5}{|l|}{ Extranodal disease } \\
\hline Present & 07 & 0.62 & 05 & 0.48 \\
\hline Absent & 20 & & 20 & \\
\hline \multicolumn{5}{|l|}{ Bulk disease } \\
\hline Present & 04 & 0.65 & 04 & 0.7702 \\
\hline Absent & 23 & & 21 & \\
\hline \multicolumn{5}{|l|}{ Mediastinal disease } \\
\hline Present & 10 & 0.29 & 10 & 0.52 \\
\hline Absent & 17 & & 15 & \\
\hline \multicolumn{5}{|l|}{ CNS involvement } \\
\hline Present & 02 & 0.56 & 02 & 0.56 \\
\hline Absent & 13 & & 13 & \\
\hline \multicolumn{5}{|l|}{ BM infiltration } \\
\hline Present & 11 & 0.94 & 08 & 0.79 \\
\hline Absent & 16 & 0.94 & 17 & \\
\hline \multicolumn{5}{|l|}{ Level of DHL } \\
\hline$\leq \mathrm{l} 250 \mathrm{U} / \mathrm{dl}$ & 06 & 0.69 & 06 & 0.69 \\
\hline$>250$ and $<450 \mathrm{U} / \mathrm{dl}$ & 08 & & 08 & \\
\hline$\geq 450 \mathrm{U} / \mathrm{dl}$ & 05 & & 05 & \\
\hline \multicolumn{5}{|l|}{ Immunophenotype } \\
\hline B & 18 & 0.42 & 16 & 0.60 \\
\hline $\mathrm{T}$ & 03 & & 03 & \\
\hline
\end{tabular}

$\mathrm{NCC}=$ malignant lymphoma small non-cleaved cell; $\mathrm{DSCC}=$ malignant lymphoma diffuse small cleaved cell; DMSLC = malignant lymphoma diffuse mixed small and large cell; DLC = malignant lymphoma diffuse large cell; FM SC LC = malignant lymphoma follicular mixed small cleaved and large cell; BM = bone marrow 
rate of $\mathrm{CR}$ to the protocols analyzed were: $\mathrm{CHOP} 61 \%$, BACOP $41 \%$ and MACOP-B 50\% ( $P=0.1642)$. The median 5-year survival rates were: OS $62 \%$ and DFS $52 \%$ for high grade lymphoma, $57 \%$ and $49 \%$ for intermediate grade and $63 \%$ and $52 \%$ for low grade lymphoma respectively.

\section{DISCUSSION}

We analyzed patients with NHL divided into three subgroups in accordance with the WF classification and evaluated the variables that could demonstrate prognostic value. A second statistical study was done to check the influence of treatment on the survival for each variable studied at the first step.

The intermediate grade lymphomas presented results comparable to those described in the literature, probably because this was the largest group of patients. In this group the variables associated with worse prognosis were: $B$ symptoms $(P<0.01)$; performance status III and IV $(P<0.01)$ and CNS involvement $(P=0.006)$. There are reports that patients with a diagnosis of performance status of III and IV is related to high cell proliferation and this fact could have implications of an unfavorable prognosis. ${ }^{14}$ It is well known that better therapeutic results are associated with longer survival in patients that have a good performance status at the diagnosis. . $^{5,713}$

Involvement of the CNS generally implies frequently relapsing disease. ${ }^{15}$ Some studies have suggested that patients with bone marrow involvement have a higher risk of presenting CNS infiltration. ${ }^{15}$ This aspect was observed in our study.

The small number of patients with high and low grade lymphomas made it impossible to demonstrate statistically some important variables reported elsewhere such as: bone marrow and CNS involvement, bulk disease, mediastinal disease, high levels of LDH and age above 60 years. ${ }^{15}$

Table 4- Distribution of 93 patients with non-hodgkin lymphomas according to the treatment received

\begin{tabular}{|c|c|c|c|}
\hline & \multicolumn{3}{|c|}{ Lymphoma grade } \\
\hline & High & Intermediate & Low \\
\hline Macop-B & 6 & 14 & 4 \\
\hline Promace-C yta BO M & 1 & 7 & 3 \\
\hline BFM -83 & 1 & 3 & 3 \\
\hline M VPP & 1 & 12 & 2 \\
\hline BACOP & 2 & 13 & 8 \\
\hline $\mathrm{CHOP}$ & 5 & 2 & 2 \\
\hline Total & 16 & 52 & 25 \\
\hline
\end{tabular}

Comparisons between types of treatment in each lymphoma grade. High $\mathrm{P}=0.7$; Intermediate $\mathrm{P}=0.16$; Low $\mathrm{P}=0.27$
For high grade lymphomas the following variables were related to worse disease: yellow race $(P=$ $0.003)$, ECOG III and IV ( $P<0.01)$ and extranodal disease $(P<0.01)$. After including the treatment, the only variable associated with an unfavorable prognosis for survival was CNS infiltration $(P<0.01)$. Many reports have demonstrated that extranodal disease, especially if there are two or more involved sites, is associated with worse evolution. ${ }^{3,16}$ This is valid for all kinds of lymphomas. This fact, even if negated by others, makes us think that it may be necessary to have other factors associated with the extranodal disease in order to cause a worse prognosis. ${ }^{5,6}$ For low grade lymphomas, only the lymphoplasmocytoid subset $(P=0.018)$ had prognostic value, and in the second study no variable was associated with treatment and survival.

The overall survival and DFS for all grades of the WF classification are quite similar to those of other studies, although our patients were treated with different non-randomized protocols. Costa et al. ${ }^{7}$ had an OS of $54 \%$ and a 5 -year DFS of $52 \%$ in a series of 54 high and intermediate grade lymphomas, most of which with diffuse histological patterns and advanced stage disease. Klimo \& Connors $^{17}$ found a median 8year survival of $62 \%$ and a DFS of $52 \%$ in 126 patients with diffuse large cell lymphoma. For the low-grade lymphoma, the OS and DFS were comparable to the many other studies that included patients with advanced stage disease. ${ }^{3}$

A relationship between a high level of $L D H$ and a worse survival for NHL has very often been reported..$^{5,14,18}$ Schneider et al. ${ }^{21}$ pointed out the importance of this marker even when not considering the extent of the tumor nor the bulk mass burden. In our intermediate group, an LDH higher than $450 \mathrm{U} / \mathrm{dl}$ had some relation with survival, with a $p$-value close to significance $(P=0.055)$.

Bone marrow involvement was not related to unfavorable survival in the three studied groups. We analyzed the presence or absence of focal or diffuse infiltration. For the intermediate grade lymphomas, there was a tendency towards diffuse marrow involvement and worse survival $(P=0.086)$. Data from the National Cancer Institute, Bethesda, USA, has postulated that marrow involvement means a poor prognostic factor for survival. A similar analysis performed at the M.D. Anderson Hospital was not able to predict this variable as an unfavorable factor. However, the association of bone marrow involvement, high LDH level and a high rate of cellular proliferation seems to have some prognostic meaning. ${ }^{14}$ In both of our statistical analyses immunological phenotyping did not 
influence the survival of the three different groups.

Our treatment was based on the first histological WF classification, but 43 of the 113 evaluated patients from the first study had their histological subtype changed after review. Thus, the philosophy of basing treatment on the initial diagnosis generated a miscellany of analyses. Despite having a small sample size, especially when analyzing each chemotherapy scheme in isolation, our data are similar to those in other reports. ${ }^{8,20}$ Although MACOP-B seems to be better than $\mathrm{CHOP}$ for $\mathrm{CR}$ rates, we can conclude that they are similar when considering OS and DFS. This conclusion has been confirmed by other reports in the last five years. ${ }^{21}$

For the largest group, the intermediate lymphomas, there were no differences between $\mathrm{CHOP}, \mathrm{BACOP}$ and MACOP-B relating to survival $(P=0.1642)$. When considered separately, CHOP showed a better rate of CR, 8/13 (61.50\%), but this was not significant. At present, there is a world trend to use CHOP as the treatment schedule for aggressive lymphoma due to results that are similar and comparable to more toxic third-generation protocols. ${ }^{7,8,13}$

For low-grade lymphomas our results are slightly inferior to those of other reports, but are comparable to studies that included advanced stage disease. ${ }^{22}$ Even though $28 \%$ of those patients were treated with third-generation schemes and the others with $\mathrm{CHOP}$, BACOP, M VPP or COP, no chemotherapy scheme was seen to be superior in relation to the prognosis $(P=$ 0.2717). New treatment forms are being used for low- grade Iymphomas, especially purine analogs, interferon and allogeneic and autologous bone marrow transplantation. However their efficacy is still limited when compared with classic treatments such as usage of alkylating agents or aggressive chemotherapy. ${ }^{23,24}$ We believe that new studies and protocols are necessary in order to have a more precise conclusion about the best treatment for low grade lymphomas. $^{25}$

A new attempt at classifying NHL has recently been made. In this new classification, Iymphoproliferative disorders are divided into B, T or NK diseases. ${ }^{26}$ The cytogenetic characteristics and oncogenesis with their respective molecular rearrangements are considered in trying to describe each known pathology as an isolated entity. It is designated the REAL classification, signifying a consensus between American, European and Asian hemato-pathologists. This classification appears to have achieved the ideal, but more time and experience will be required before reaching a definitive conclusion on such a complex subject.

It is clear that we need to bring together clinical hematologists, pathologists and cytogeneticists in Brazil, in order attain a better understanding of the complex setting of this disease. Cooperation between institutions in different areas of the country could achieve clinical and therapeutic results. Only in this way will there be a commonality of spirit leading to a better understanding of NHL in Brazil.

\section{REFERENCES}

1. Carbone PP, Kaplan HS, Musshoff K. Report of the committee on Hodgkin's disease staging. Cancer Res 1971;31:1860-1.

2. Rosenberg SA. Validity of Ann Arbor staging of the non-Hodgkin's lymphomas. Cancer Treat Rep 1977;61:1023-7.

3. Romaguera JE, MCLaughlin P, North L, et al. Multivariate analysis of prognostic factors in stage IV follicular low-grade lymphoma: a risk model. J Clin Oncol 1991;9:762-9.

4. Velasquez WS, Jagannath S, Tucker SL. Risk classification of the basis for clinical staging of diffuse large cell lymphoma derived from 10year survival data. Blood 1989;74:551-7.

5. Vitolo U, Bertini $M$, Brusamolino $E$, et al. Macop-B treatment in diffuse large-cell lymphoma: identification of prognostic groups in an Italian multivariate study. J Clin Oncol 1992;10:219-27.

6. Shipp MA, Harrington DP, Klatt MM, et al. Identification of major prognostic subgroups of patients with large-cell lymphoma treated with m-Bacod or M-Bacod. Ann Intern Med 1986;104:757-65.

7. Costa AM, Froimtchuk MJ, Robinowits M, Olivetto LO, Allanse Gil RA. Long-term results with Macop- $B$ in the treatment of aggressive nonHodgkin lymphomas. Am J Clin Oncol 1994;17:323-7.
8. Summary and Description of a Working Formulation for Clinical Usage: National Cancer Institute sponsored study of classification of nonHodgkin's lymphomas. Cancer 1992;49:2112-35.

9. Pilleri AS, Sabatini E, Falini B. Immunohistochemical detection of the multidrug transport protein P-170 in human normal tissues and malignant lymphomas. Histopathol 1991;19:131-40.

10. Longo D, DeVita VT, Duffey P. Randomized trial of Promace-Mopp (PM) (day 1 and 8) vs. Promace-CytaBOM (PC) in stage II to IV aggressive non-Hodgkin's Iymphoma. Proc Am Soc Clin Oncol 1987;6:206 (abstract).

11. Hoelzer ET, Löffer $\mathrm{H}$, Bodenstein $\mathrm{H}$, et al. Intensified therapy in acute lymphoblastic and acute undifferentiated leukemia in adults. Blood 1984;54:38-47.

12. Yi PI, Coleman S, Saltz L, et al. Chemotherapy for large-cell lymphoma: a status update. Semin Oncol 1990;17:60-73.

13. Young RC, Longo DL, Gladstein $\mathrm{E}$, et al. The treatment of indolent lymphomas: watchful waiting for aggressive combined modality treatment. Semin Hematol 1988;25(suppl 2):11-6.

14. Kaplan EL, Meyer P. Non-parametric estimation from incomplete observation. J Am Stat Assoc 1958;53:457-81. 
15. Silvestrini R, Costa A, Boracchi P, Giardini R, Rilke F. Cell proliferation as a long term prognostic factor in diffuse large-cell lymphomas. Int J Cancer 1993;54:231-6.

16. Jagannath S, Velasquez SW, Tucker SL, et al. Tumor burden assessment and its implication for a prognostic model in advanced diffuse largecell lymphoma. J Clin Oncol 1986;4:859-65.

17. Shipp AM, Yeap YB, Harrington DP, Klatt MM, et al. The m-Bacod combination chemotherapy regimen in large-cell lymphoma: analysis of the complete trial and comparison with the M-Bacod regimen. J Clin Oncol 1990;8:84-93.

18. Kirn D, Mauch P, Shaffer K, Pinkus G, et al. Large-cell and immunoblastic lymphoma of the mediastinum: prognostic features and treatment outcome in 57 patients. J Clin Oncol 1993;11:1336-43.

19. Klimo P, Connors J. MACOP-B chemotherapy for the treatment of diffuse large-cell lymphoma. Ann Intern Med 1985;102:596-602.

20. Danieu L, Wang G, Koziner B. Predictive model for prognosis in advanced diffuse histiocytic lymphoma. Cancer Res 1986;46:5372-9.

21. Schneider RF, Seibert K, Passe S. Prognostic significance of serum lactate dehydrogenase in malignant lymphoma. Cancer 1980;46:139-43.

22. Miller TP, Lippman SM, Spier CM. HLA-DR (la) immune phenotype predicts outcome for patients with diffuse large-cell lymphoma. J Clin Immunol 1988;82:370-2.

23. Gordon LE, Harrington D, Andersen R, et al. Comparison of a second generation combination chemotherapy regimen (m-Bacod) with a standard regimen (Chop) for advanced diffuse non-Hodgkin's lymphoma. N Engl J Med 1992;327:12-8.

24. Lyang R, Chiu E, Lake SL. Management of low-grade lymphomas in Hong Kong Chinese. Oncology 1991;48:121-4.

25. McKelvey EM, Gottlieb JA, Wilson HE. Hydroxydaunomycin (adriamycin) combination chemotherapy in malignant lymphoma. Cancer 1976;38:1484-93.

26. Portlock CS, Rosenberg SA. No initial therapy for stage III and IV nonHodgkin Iymphomas of favorable histologic types. Ann Intern Med 1979;90:10-3.

27. Cheson B. New chemotherapeutic agents for the treatment of low grade non-Hodgkin's lymphomas. Semin Oncol 1993;20(suppl 5):96-110.

28. Chan JKC, MBBS, Banks PM, Cleary ML, et al. A revised EuropeanAmerican classification of lymphoid neoplasms proposed by the international lymphoma study group: a summary version. Am J Clin Pathol 1993;103:543-60. esu mo

CONTEXTO: $\mathrm{N}$ a doença de Hodgkin, cada estágio clínico ou patológico pode ser relacionado com a extensão da área envolvida e predizer a próxima região a natômica de risco para disseminação.

OBJ ETVO: Esta belecer os fa tores prognósticos que melhor predizem sobrevida em LN H.

\section{TIPO DE ESTUDO: Estudo retrospectivo}

LOCAL: Disciplina de Hematologia e Hemoterapia, Universidade Federal de São Paulo - Escola Paulista de Medicina.

PARTICIPANTES: 142 pacientes com LNH diagnosticados entre fevereiro de 1988 e março de 1993.

VARIÁVEIS ESTUDADAS: Tipo histológico, sexo, idade, raça, sintomas, sitação "performance", estágio, doença extranodal, desenvolvimento de Bulk, comprometimento mediastinal, envolvimento do SNC, infiltração da medúla óssea, nível de desidrogenose láctica, fenótipo imune.

RESULTADOS: A o primeiro estudo (113 pacientes), as seguintes variáveis tiveram uma pior influência na sobrevida: raça amarela $(P<0.1)$; ECO G II, III e IV $(P<0.1)$ e doença extranodal $(P<0.1)$ para os linfomas de alto grau; sintomas constitucionais $(P<0.1)$, ECO G II, III e IV $(P<0.1)$ e envolvimento de SN C $(P<0.1)$ para os linfomas de grau intermediário e 0 subtipo linfoplasmocitóide $(P=0.0186)$ para os linfomas de baixo grau. A o segundo estudo (93 pacientes), quando inclui-se o tratamento, as variáveis relacionadas a sobrevida foram : envolvimento de SN C $(P<0.1)$ para o linfomas de alto grau; sintomas constitucionais $(P<0.1)$, ECOG II, III, IV $(P=0.0185)$ e envolvimento de SN C $(P<0.1)$ para o grupo intermediário. $N$ enhuma variável relacionou-se com a sobrevida para os linfomas de baixo grau.

CONCLUSÕES: $0 \mathrm{~s}$ linfomas de grau intermediário, provavelmente devido ao maior número de pacientes, foram mais compatíveis com os dados encontrados na literatura. Neste caso específico, o tratamento não influenciou a sobrevida.

PALAVRAS-CHAVE: Linfoma não-Hodgkin. Fatores prognóstico. Sobrevida.

\section{publishing information}

Karin Zattar Cecyn, MD. Assistant Physician, Discipline of Hematology and Hemotherapy, Universidade Federal de São Paulo/Escola Paulista de Medicina, São Paulo, Brazil.

José Salvador Rodrigues de Oliveira, MD, PhD. Adjunct Professor, Discipline of Hematology and Hemotherapy, Universidade Federal de São Paulo/Escola Paulista de Medicina, São Paulo, Brazil.

Antônio Correia Alves, MD, PhD. Adjunct Professor, Discipline of Anatomy Pathologic, Universidade Federal de São Paulo/Escola Paulista de Medicina, São Paulo, Brazil.

Maria Regina Regis Silva, MD, PhD. Adjunct Professor, Discipline of Anatomy Pathologic, Universidade Federal de São Paulo/Escola Paulista de Medicina, São Paulo, Brazil.

José Kerbauy, MD, PhD. Titular Professor, Discipline of Hematology and Hemotherapy, Universidade Federal de São Paulo/Escola Paulista de Medicina, São Paulo, Brazil.

Sources of funding: Not declared.

Conflict of interest: Not declared.

Last received: 4 March 1999.

Accepted: 14 July 1999

Address for correspondence

Karin Zattar Cecyn

Universidade Federal de São Paulo/Escola Paulista de Medicina,

Disciplina de Hematologia e Hemoterapia.

Rua Napoleão de Barros, 715

São Paulo/SP - Brasil - CEP 04023-902

e-mail: cecyn@uol.com.br 